\title{
PERANCANGAN MESIN CUTTING CHEESE BLOCK DENGAN CUTTING TOOLS KAPASITAS 20 KG
}

\author{
Jatira', Amri Abdulah² $^{2}$, Solihin ${ }^{3}$ \\ ${ }^{1,2,3}$ Program Studi Teknik Mesin, Sekolah Tinggi Teknologi Wastukancana
}

\begin{abstract}
Absract
Cutting cheese blocks that are done manually by using a knife makes the cutting process takes a long time so that the operator has difficulty in achieving predetermined targets. Cheese cutting machine is a machine with a pneumatic system that uses wind power as a driving force to drive cheese. The purpose of this study is to provide an overview of the design of cheese cutting machines so that the process of cutting cheese, especially in the field of nutrition becomes faster. Retrieval of data in this study include direct observation, interviews and literature studies. The results obtained are in terms of quality and quantity. This pneumatic system of cheese cutting machine is seen in terms of the quality of the results of the cheese slices being uniform compared to manually cutting. Whereas when viewed in terms of quantity this machine is capable of producing 31.65 blocks compared to manual cutting which is only 6.4 blocks of cheese. From these results it can be concluded that with this cheese cutting machine the cutting process becomes faster with a uniform size.
\end{abstract}

\begin{abstract}
Abstrak
Pemotongan keju blok yang dilakukan secara manual dengan menggunakan pisau membuat proses pemotongan menjadi lama sehingga operator kesulitan dalam mencapai target yang telah ditentukan. Mesin pemotong keju merupakan mesin dengan sistem pneumatik yaitu memanfaatkan tenaga angin sebagai penggerak untuk mendorong keju. Tujuan penelitian ini untuk memberikan gambaran rancangan mesin pemotong keju agar proses pemotongan keju terutama dalam bidang insutri menjadi lebih cepat. Pengambilan data pada penelitian ini yaitu meliputi observasi secara langsung, wawancara dan studi literatur. Hasil penelitian yang diperoleh adalah dari segi kualitas serta kuantitasnya. Mesin pemotong keju dengan sistem pneumatik ini dilihat dari segi kualitasnya hasil potongan keju menjadi seragam dibandingkan jika memotong secara manual. Sedangkan jika dilihat dari segi kuantitasnya mesin ini mampu menghasilkan 31,65 blok dibandingkan dengan pemotongan manual yang hanya 6,4 blok keju. Dari hasil tersebut dapat disimpulkan bahwa dengan mesin pemotong keju ini proses pemotongan menjadi lebih cepat dengan ukuran yang seragam.
\end{abstract}

Kata kunci : Perancangan, Mesin Pemotong Keju, Pneumatik.

\section{Pendahuluan}

Keju adalah produk pangan olahan yang dibuat dari dadih susu. Dadih berasal dari penggumpalan bagian kasein dari susu dan susu skim. Penggumpalan ini terjadi dengan adanya enzim atau dengan peningkatan keasaman susu. Keju adalah salah satu bahan pangan berasal dari susu sebagai upaya memperpanjang masa simpan susu tersebut. Murti dan Hidayat, (2009). Penggumpalan curd dapat disebabkan oleh penambahan enzim renet atau enzim proteolitik lainnya yang dihasilkan oleh bakteri. Sari et al., (2014). Keju memiliki hampir semua zat gizi pada susu, seperti protein $12-16 \%$, lemak $0-12 \%$, kalsium $0,8 \%$, vitamin A $0-1 \%$ riboflavin $2,8 \%$, yang bermanfaat bagi kesehatan. Winarno dan Fernandez, (2007).

Terdapat berbagai jenis keju berdasarkan asal pembuatan keju, jenis susu yang digunakan, metode pembuatannya dan perlakuan yang digunakan dalam pematangan keju. Keju berdasarkan teksturnya dibedakan menjadi 4 yaitu keju lunak, keju setengah lunak, keju keras dan keju sangat keras. Keju dianggap lunak dengan kadar air lebih besar dari $40 \%$, keju setengah lunak yaitu dengan kadar air 36$40 \%$, keju keras yaitu dengan kadar air 25-36\% dan keju sangat keras dengan kadar air kurang dari $25 \%$ Buckle et al., (2007). Keju dapat dimatangkan dengan bakteri, jamur, kombinasi bakteri dan jamur, atau dapat juga dibiarkan tanpa dimatangkan. Jenis keju dengan cara pengolahan paling sederhana yaitu keju segar (fresh cheese).

\section{Studi literatur \\ 2.1. Definisi pemotong Keju}


Mesin pemotong keju atau cheesse cutting merupakan mesin yang digunakan dalam dunia industri khususnya industri pangan yang bergerak dibidang pengolahan keju, mesin ini digunakan untuk memotong keju blok menjadi ukuran yang lebih kecil, agar mudah untuk melakukan proses pengolahan selanjutnya. Biasanya penggerak mesin menggunakan tenaga angin yang diteruskan oleh piston dengan gerakan ganda (maju dan mundur) untuk mendorong keju hingga mengenai permukaan potong berupa pisau atau kawat stainless

\subsection{Keju}

Definisi Keju Menurut Nurhidayati (2003), keju sebagai produk dengan bahan dasar susu merupakan alternatif yang dapat digunakan untuk memenuhi kebutuhan protein hewani. Selama ini produk pengolahan keju melalui fermentasi sering terkontaminasi oleh yeast sebagai (secondary microflora). Namun telah diteliti bahwa keberadaan mikroflora sekunder tersebut justru memberikan kontribusi yang signifikan pada proses pematangan keju Balia, (2006). Keju dibuat dengan cara koagulasi (penggumpalan) casein susu membentuk dadih atau curd. Dadih susu kemudian dipanaskan dan dipres sehingga menghasilkan dadih keras, yang kemudian dilakukan pemeraman atau pematangan keju. Di samping menggunakan rennet, penggumpalan casein dapat juga dilakukan dengan fermentasi bakteri asam laktat.

\subsection{Proses Pemotongan}

Memotong adalah pekerjaan yang dilakukan untuk mengecilkan ukuran suatu bahan baik dengan pisau atau dengan alat pemotong lainnya pada arah melintang panjang serat bahan. Ukuran dari bahan yang terbentuk relatif panjang atau tebal. Mengiris adalah mengecilkan ukuran suatu bahan dengan menggunakan pisau untuk mendapatkan ukuran panjang lebih kecil dan tipis dengan arah melintang atau sejajar panjang bahan yang dipotong Supriadi, (2001) dalam Kuswono, (2007).

Tujuan pemotongan untuk mengecilkan atau memperpendek bahan. Bentuk dan ukurannya kadang-kadang tidak diperhatikan, tetapi dapat pula disesuaikan dengan keperluan. Untuk mencegah kerusakan struktur bahan yang dipotong misalnya menjadi memar, baik pada pemotongan dengan menggunakan mesin maupun secara manual.

\subsection{Perancangan}

Perancangan merupakan suatu cara menciptakan gagasan baru dan kemudian mengkomunikasikan gagasan-gagasan tersebut kepada orang lain dengan cara yang mudah dipahami. Pemilihan material dan proses pembuatan alat merupakan bagian penting dalam desain teknik. Pengumpulan material dan proses pembuatan perlu dilaksanakan sebagai bagian dari pembuatan alat dalam rancang bangun Giesecke et.al., (2001) dalam Yenti, (2014). Merancang suatu produk akan melalui tahapan proses awal. Prinsipprinsip perancangan Hurst, (2006) dalam Pratama, (2014).

\subsection{Perhitungan Penumatik.}

\section{Tekanan}

Pada penerapan sistem pemanfaatan pnuematik maka tekanan adalah salah satu faktor utama yang harus diketahui, dan untuk mengetahui tekanan yang diperlukan, maka dapat menggunakan rumus dari Drs Sugihartono, (1996) :

$$
\mathrm{F}=\mathrm{m} . \mathrm{a}
$$

Dimana :

$$
\begin{aligned}
\mathrm{F} & =\text { Gaya }(\mathrm{N}) \\
\mathrm{m} & =\text { Masa Benda }(\mathrm{Kg}) \\
\mathrm{a} & =\text { Percepatan Dari Benda }(\mathrm{m} / \mathrm{s} 2)
\end{aligned}
$$

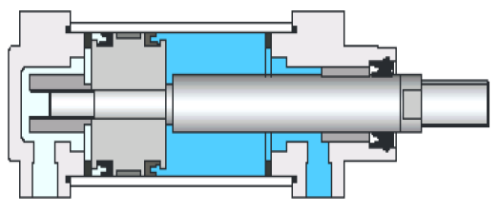

Gambar 2.1. Silinder Kerja Ganda (Drs Sugihartono 1996)

\section{Analisa aliran fluida.}

Aliran fluida yang melewati saluran yang memiliki perbedaan luas penampang debit udara akan tetap , namun kecepatannya akan berubah sebanding dengan perubahan luas penampangnnya Wirawan Subodo DKK, (2008) sehingga ditentukan oleh rumus dibawah ini :

$$
\mathrm{Q} 1=\mathrm{Q} 2 \text {, sehingga } \frac{V_{1}}{V_{2}}=\frac{A_{2}}{A_{2}}
$$

Atau untuk menentukan debit aliran fluida ditentukan dengan rumus :

$$
\mathrm{Q}=\mathrm{A} . \mathrm{V}
$$

Dimana :

$$
\begin{aligned}
& \text { Q : debit aliran (m3/dtk). } \\
& \text { A : Luas permukaan }(\mathrm{m} 2) \\
& \text { V : kecepatan Uadra mengalir }(\mathrm{m} / \mathrm{dtk})
\end{aligned}
$$

\section{Analisa kecepatan torak.}

Kecepatan rata-rata torak tergantung dari gaya luar yang melawan torak (beban) yang terdiri dari gerakan maju dan gerakan mundur serta ukuran lubang aliran Wirawan Subodo DKK, (2008), Kecepatan torak dapat diatur dengan katup pengontrol aliran dan dapat ditingkatkan dengan katup pembuang cepat yang dipasang pada sistem kontrol tersebut atau dengan perhitungan cara perhitungan dibawah ini:

$$
\mathrm{Vmaju}=\mathrm{Q} / \mathrm{A}
$$

Vmundur $=\mathrm{Q} / \mathrm{An}$

\section{Dimana :}

$\mathrm{V}:$ kecepatan torak $(\mathrm{m} / \mathrm{s})$

$\mathrm{Q}$ : debit aliran udara (ltr/mnt)

A : Luas Silinder (m2)

Ak : Luas batang piston (m2)

An: A-Ak $\left(\mathrm{m}^{2}\right)$ 


\section{Gaya piston}

Gaya (F) efektif piston mempunyai dua arah yaitu maju dan mundur, Gaya efektif piston saat maju dapat dihitung dengan rumus dari Drs Sugihartono (1996):

Fmaju $=$ A $. \rho-$ Rr.

Gaya efektif piston saat Mundur dapat dihitung dengan rumus :

$$
\text { Fmundur }=\mathrm{p} \cdot \frac{\pi}{4} \cdot(\mathrm{D} 2-\mathrm{d} 2)-\mathrm{Rr} .
$$

Dimana :

A : Luas permukaan silinder pneumatic $\left(\mathrm{m}^{2}\right)$

$\mathrm{P}$ : Tekanan kerja untuk pneumatic $\left(\mathrm{N} / \mathrm{m}^{2}\right)$

$\mathrm{Rr}$ : Gaya gesek (3 - $20 \%)$

D : Diameter silinder (m)

$\mathrm{d}$ : Diameter batang piston $(\mathrm{m})$

\section{Konsumsi udara tiap langkah}

Komponen-komponen pneumatic dapat bergerak karena adanya udara yang dimampatkan melalui kompressor, tiap-tiap komponen memiliki bentuk dan ukuran yang berbeda sehingga kebutuhan udaranya berbeda pula. Berikut bentuk salah satu perhitungan konsumsi udara.

Konsumsi udara tiap langkah piston sistem double action Andrew Parr. (2003):

Konsumsi udara langkah maju

$$
\mathrm{V} 1=\mathrm{p} \cdot \frac{\pi}{4} \cdot \mathrm{d} 2 . \mathrm{h}
$$

Konsumsi udara langkah mundur

$$
\mathrm{V} 2=\mathrm{p} \cdot \frac{\pi}{4} \cdot(\mathrm{D} 2-\mathrm{d} 2) . \mathrm{h}
$$

Keterangan :

V1= Konsumsi udara langkah maju (m3)

V2= Konsumsi udara langkah mundur (m3)

$\mathrm{D}=$ Diameter piston silinder $(\mathrm{m})$

$\mathrm{d}=$ Diameter batangt piston $(\mathrm{m})$

$\mathrm{p}=$ Tekanan kerja (bar)

$\mathrm{h}=$ Panjang Langkah $(\mathrm{m})$

\section{Udara yang diperlukan tiap menit.}

Untuk menentukan berapa debit udara yang diperlukan untuk menggerakan silinder piston gerak maju dan mundur harus diketahui terlebih dahulu perbandingan kompresinya.

\section{Perbandingan Kompresi}

Perbandingan kompresi dapat dihitung dengan menggunakan rumus Drs. Sugihartono, (1996) :

$$
\begin{aligned}
& \text { Rasio kompresi }=\frac{101,3+\text { tekanan operasi }}{101,3} \\
& \text { Qmaju }=\frac{\pi}{4} . \mathrm{D}_{2} . \mathrm{H} . \mathrm{n} . \text { Rasio kompresi... } \\
& \text { Qmundur }=\frac{\pi}{4} .\left(\mathrm{D}_{2}-\mathrm{d}_{2}\right) . \mathrm{h} . \mathrm{n} . \mathrm{RK} \ldots \ldots \ldots
\end{aligned}
$$

\section{Dimana :}

Q : Volume udara yang diperlukan (m3 / mnt)

D2 : Diameter Silinder (m)

d2 : Diameter batang torak (m)

$\mathrm{h}$ : Panjang langkah $(\mathrm{m})$

p : Tekanan kerja (bar)

\section{n : Banyaknya langkah (menit)}

\section{Perencanaan silinder penumatik.}

Untuk menghitung berapa besar diameter batang piston pneumatik yang digunakan, maka dapat menurunkan dari rumus utrama dengan menggunakan rumus Drs. Sugihartono, (1996) dibawah ini :

$$
\begin{aligned}
& \mathrm{F}=\mathrm{p} \cdot \frac{\pi \cdot \mathrm{d}^{2}}{4}-\mathrm{R} \\
& \mathrm{d} 2=\frac{F+R}{p \times 7.86} \ldots \ldots \ldots
\end{aligned}
$$

dimana :

$$
\begin{aligned}
& \mathrm{d}=\text { diameter batang piston }(\mathrm{cm}) \\
& \mathrm{F}=\text { gaya }(\mathrm{N}) \\
& \mathrm{R}=\text { Gesekan }(\mathrm{N}) \text { diambil } 3-20 \% \text { dari gaya } \\
& \quad \text { terhitung } \\
& \mathrm{p}=\text { Tekanan kerja untuk pneumatik (Bar) } \\
& \quad \text { Nilai } 7,86 \text { didapat dari }\left(\frac{\pi}{4}\right)
\end{aligned}
$$

\subsection{Kompresor.}

\section{Definisi Kompresor}

Pemampat atau kompresor adalah alat mekanik yang berfungsi untuk meningkatkan tekanan fluida mampu mampat yaitu gas atau udara. tujuan meningkatkan tekanan dapat untuk mengalirkan atau kebutuhan proses dalam suatu sistem proses yang lebih besar (dapat sistem fisika maupun kimia contohnya pada pabrik-pabrik kimia untuk kebutuhan reaksi).

\section{Daya Kompresor}

Menurut Sularso, Haruo Tahara, (2000) dalam buku yang berjudul pompa dan kompresor, untuk mencari daya kompresor hal yang pertana dilakukan adalah mengetahui berapa besar perpindahan torak yang terjadi, serta menentukan besarnya efisiensi volumetris yang akan direncanakan, untuk kemudian mendapatkan nilai volume udara yang keluar dari kompresor, sehingga dapat dicari daya yang diperlukan, adapun rumus yang digunakan adalah sebagai berikut Sularso, Haruo Tahara, (2000) :

Menghitung perpindahan torak

$$
\mathrm{Q}_{\mathrm{th}}=\frac{\pi}{4}(2 \mathrm{D} 2-\mathrm{d} 2) \mathrm{SN}
$$

Dimana :

$$
\begin{aligned}
& \mathrm{Q}_{\mathrm{th}}=\text { Perpindahan Torak }(\mathrm{m} 3 / \mathrm{min}) \\
& \mathrm{D}=\operatorname{Diameter} \text { silinder }(\mathrm{m}) \\
& \mathrm{d}=\text { Diameter Batang Torak }(\mathrm{m}) \\
& \mathrm{S}=\operatorname{Langkah} \text { Torak }(\mathrm{m}) \\
& \mathrm{N}=\text { Putaran }(\mathrm{rpm})
\end{aligned}
$$

Efisiensi Volumetris Sularso, Haruo Tahara. (2000) :

$$
\boldsymbol{\eta} \mathbf{v}=\frac{Q_{s}}{Q_{t h}}
$$

Dimana

$$
\begin{aligned}
& \boldsymbol{\eta} \mathbf{v}=\text { Efisiensi volumetris } \\
& \text { Qs = Volume gas yang dihasilkan (m3/min) } \\
& \text { Qth = Perpindahan Torak (m3/min) }
\end{aligned}
$$

Menghitung Daya. Sularso, Haruo Tahara. (2000) :

$$
\mathrm{P}_{\mathrm{ad}}=\text { Qs x 4,7074. }
$$

Dimana : 
$\mathrm{P}_{\mathrm{ad}}=$ Daya Kompresor $(\mathrm{Kw})$

$\mathrm{Q}_{\mathrm{s}}=$ Volume gas dihasilkan (m3/min)

Sementara nilai 4,7074 adalah nilai yang diperlukan untuk memampatkan $1 \mathrm{~m} 3 /$ min udara standar menjadi $7 \mathrm{kgf} / \mathrm{cm} 2$.

Daya poros Kompresor

Untuk menghitung daya poros yang diperlukan kompresor adalah Sularso, Haruo Tahara. (2000) :

$$
\mathrm{P}_{\mathrm{s}}=\frac{\mathrm{P}_{\mathrm{ad}}}{\eta_{\mathrm{ad}}}
$$

Dimana :

$$
\begin{aligned}
& \mathrm{P}_{\mathrm{s}}=\text { Daya Poros }(\mathrm{Kw}) \\
& \mathrm{P}_{\mathrm{ad}}=\text { Daya Kompresor }(\mathrm{kw}) \\
& \boldsymbol{\eta}_{\mathrm{ad}}=\text { Efisiensi adiabatik rencana }(\%)
\end{aligned}
$$

\subsection{Menentukan Daya Motor Penggerak}

Menurut Sularso, Haruo Tahara. (2000) daya motor penggerak harus diambil $5-10 \%$ dari hasil perhitungan daya poros yang diperlukan atau dibutuhkan oleh kompresor, daya penggerak dari motor ditentukan oleh rumus Krist Thomas. (1993) dibawah ini :

$$
\mathrm{P}_{\mathrm{m}}=\mathrm{Ps} /(5 \mathrm{~s} / \mathrm{d} 10 \%)
$$

dimana :

$$
\begin{aligned}
& \mathrm{P}_{\mathrm{m}}: \text { daya motor }(\mathrm{kw}) \\
& \mathrm{P}_{\mathrm{s}} \text { : daya kompresor }(\mathrm{kw})
\end{aligned}
$$

\subsection{Rangka}

Beban adalah beratnya benda atau barang yang didukung oleh suatu konstruksi atau bagan beban dan dapat dibedakan menjadi dua macam, yaitu:

\section{Beban Statis.}

Beban statis berat suatu benda yang tidak bergerak dan tidak berubah beratnya. Beratnya konstruksi yang mendukung itu termasuk beban mati dan disebut berat sendiri dari pada berat konstruksi.

\section{Beban Dinamis.}

Beban dinamis adalah beban yang berubah tempatnya atau berubah beratnya. Sebagai contoh beban hidup yaitu kendaraan atau orang yang berjalan diatas sebuah jembatan, tekanan atap rumah atau bangunan. Pada beban dapat digolongkan menjadi dua macam, yaitu:

\section{a) Beban terpusat atau beban titik.}

Beban yang bertitik pusat di sebuah titik, misal: orang berdiri diatas pilar pada atap rumah.

b) Beban terbagi.

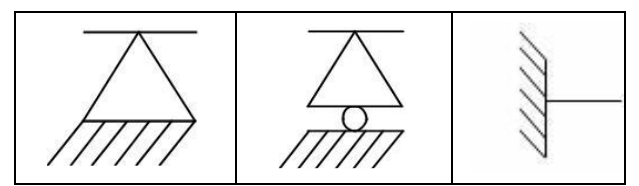

Pada beban ini masih dikatakan sebagai beban terbagi rata dan beban segitiga. Beban terbagi adalah beban yang terbagi pada bidang yang cukup luas.

Dalam perhitungan kekuatan rangka akan diperhitungkan gaya-gaya luar dan gaya-gaya dalam untuk mengetahui reaksi yang terjadi, sebagai berikut:

\section{Gaya-gaya Luar.}

Gaya-gaya luar adalah muatan dan reaksi yang menciptakan kestabilan kontruksi. Pada suatu kantilever (batang) apabila ada muatan yang diterapkan maka akan terdapat gaya reaksi yang timbul pada tumpuan. Pada kasus statik tertentu persamaan dari kesetimbangan.

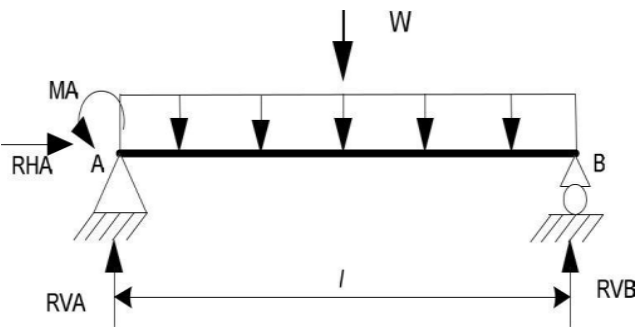

Gambar 2.2 Reaksi Gaya pada Rangka Popov, E.P. (1989)

$\sum F x=0 \rightarrow R H A=0$.

$\sum F y=0 \rightarrow R V A+R V B=W$

$\sum M A=0$

$\left(W x \frac{1}{2} x l\right)-(R V B x l)=0$.

Dengan :

$\mathrm{W}=$ beban

$1 \quad=$ panjang

$\mathrm{M} \quad=$ Momen

\section{Gaya-gaya Dalam}

Gaya-gaya dalam adalah gaya yang merambat dari beban yang tertumpu pada konstruksi yang menimbulkan reaksi gaya. Hal ini apabila ada muatan maka ada reaksi yang terjadi, yaitu:

Gaya normal $(\mathrm{N})$, merupakan gaya yang melawan muatan dan bekerja sepanjang sumbu batang.

Gaya lintang (L), merupakan gaya yang melawan muatan dan bekerja tegak lurus terhadap sumbu batang. Momen lentur (M),merupakan gaya perlawanan dari muatan sebagai penahan lenturan yang terjadi pada balok atau penahan terhadap lengkungan.

\section{Tumpuan}

Suatu konstruksi di rencanakan untuk suatu keperluan tertentu. Tugas utama suatu konstruksi adalah mengumpulkan gaya akibat beban yang bekerja padanya dan meneruskanya ke bumi. Agar dapat melaksanakan tugasnya maka konstruksi harus berdiri dengan kokoh. Suatu konstruksi akan stabil apabila diletakkan di atas pondasi atau tumpuan yang dirancang secara baik. Beberapa jenis tumpuan, yaitu:
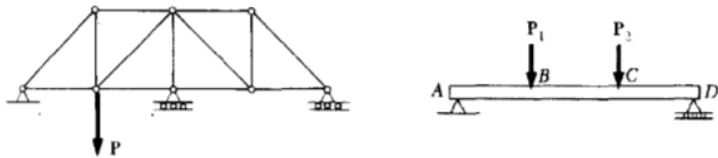


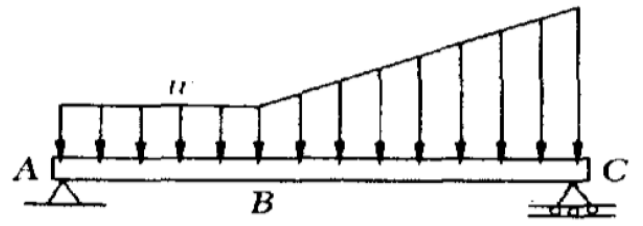

Gambar 2.3 Tumpuan

2.9. Momen Inersia Balok Besar Dan Kecil.

Momen inersia adalah momen yang terjadi pada batang yang ditumpu. Pada setiap batang dapat dihitung momen inersia yang terjadi, dengan menggunakan persamaan dibawah ini. Popov, E.P. (1989). dengan :

$$
1_{1}=1_{0}+A_{1} \times d_{1}
$$

$$
\begin{array}{ll}
\mathrm{l}_{1}=\text { momen inersia balok } & (\mathrm{mm}) \\
\mathrm{A}=\text { luas batang } & (\mathrm{mm}) \\
\mathrm{d}=\text { diameter batang } & (\mathrm{mm})
\end{array}
$$

2.10. Besar Tegangan Geser Yang Diijinkan.

Tegangan geser yang diijinkan lebih besar pada batang yang diijinkan,jika tegangan geser yang diijinkan lebih besar dari pada momen tegangan geser pada kontruksi maka kontruksi aman atau kuat menahan beban yang diterima. Pada besar tegangan geser yang diijinkan dapat dihitung dengan menggunakan persamaan Popov, E.P. (1989).

$$
\tau=\frac{M \times \gamma}{l x} \ldots
$$

dengan :

$$
\begin{aligned}
& \tau=\text { tegangan geser yang terjadi }(\mathrm{kgf} / \mathrm{mm}) \\
& \mathrm{M}=\text { momen yang terjadi }(\mathrm{kgf} / \mathrm{mm}) \\
& \mathrm{lx}=\text { momen inersia batang }(\mathrm{mm}) \\
& \gamma=\text { titik berat batang }(\mathrm{mm})
\end{aligned}
$$

\subsection{Masa Dan Gaya}

Sistem pneumatik umumnya bergantung pada tekanan dalam cairan. Sebelum membicarakan definisi tekanan, harus terlebih dahulu mengetahui apa yang dimaksud dengan istilah sehari-hari seperti berat, massa dan gaya. Berat merupakan gaya yang timbul dari tarikan gravitasi antara massa sebuah obyek dan bumi. Penulis mempunyai berat $65 \mathrm{~kg}$ di kamar mandi. Hal ini setara dengan gaya $65 \mathrm{~kg}$ antara kaki dan tanah. Oleh karena itu berat tergantung pada gaya gravitasi. Di bulan, dimana gravitasinya adalah seperenam daripada di bumi, maka penulis akan mempunyai berat sekitar $10,83 \mathrm{~kg}$; di ruang bebas berat akan menjadi nol. Dalam semua kasus, massa penulis adalah konstan.

\subsection{Tekanan}

Tekanan dalam cairan terjadi ketika ia diberi gaya. Memperbesar gaya jelas akan meningkatkan tekanan secara proporsional langsung. Mengurangi luas penampang piston A juga akan meningkatkan tekanan. Tekanan dalam cairan itu dapat didefinisikan sebagai gaya per luas penampang, atau: Andrew Parr. (2003)

$$
P=\frac{\mathrm{F}}{\mathrm{A}}
$$

\subsection{Gaya Gesek}

Gaya gesek statis maksimum adalah berbanding lurus dengan komponen gaya normal (FN) dari reaksi pada permukaan Irawan Agustinus Purna. (2017) :

$$
\mathrm{F}_{\mathrm{gm}}=\mu \mathrm{s} . \mathrm{F}_{\mathrm{N}}
$$

\section{Dimana:}

$$
\begin{aligned}
& \mu \mathrm{s}=\text { koefisien gesek statik. } \\
& \mathrm{F}_{\mathrm{gm}}=\text { gaya gesek maksimum } \\
& \mathrm{F}_{\mathrm{N}}=\text { gaya normal. }
\end{aligned}
$$

Gaya gesek kinetik dari gaya gesekan:

$$
\begin{aligned}
& \mathrm{F}_{\mathrm{gk}}=\mu \mathrm{k} . \mathrm{F}_{\mathrm{N}} \ldots \ldots \ldots \ldots \ldots \ldots \ldots \ldots \ldots \ldots \ldots \ldots \ldots \ldots \ldots \ldots \\
& \mu \mathrm{k}
\end{aligned}
$$

$\mu \mathrm{s} \& \mu \mathrm{k}$ : tidak tergantung pada luas permukaan bidang kontak. Tetapi sangat dipengaruhi sifat dari permukaan kontak.

\subsection{Menentukan Ukuran Baut Dan Mur}

Pertama-tama akan ditinjau kasus dengan pembebanan aksial murni Sularso, Kiyokatsu Suga. (1997). Dalam hal ini, persamaan yang berlaku adalah:

$$
\tau_{\mathrm{t}}=\frac{W}{A}=\frac{W}{\left(\frac{\pi}{4}\right) d_{1}^{2}}
$$

Dimana :

$$
\begin{aligned}
& \mathrm{W}=\text { beban tarik aksial pada baut }(\mathrm{Kg}) \\
& \tau_{\mathrm{t}}=\text { Tegangan tarik yang terjadi } \\
& \mathrm{d}_{1}=\text { Diameter inti }(\mathrm{mm}) \\
& \mathrm{A}=\text { Luas permukaan }
\end{aligned}
$$

Tegangan tarik yang terjadi pada baut harus lebih kecil dari tegangan tarik yang diizinkan, sehingga komponen baut tidak mengalami kerusakan, adapun persamaan nya ditulis seperti dibawah ini:

$$
\tau_{\mathrm{t}}=\frac{W}{\left(\frac{\pi}{4}\right)(0,8)^{2}} \leqq \tau_{\mathrm{a}}
$$

Dimana :

$0,8=$ besar diameter inti umum jika;

$\mathrm{d}=$ diameter luar $(\mathrm{d} \geqq 3 \mathrm{~mm}, \mathrm{~d} 1=0,8)$

$\tau_{\mathrm{a}}=$ tegangan geser yang diizinkan $(\mathrm{kg} / \mathrm{mm} 2)$

Dari ke dua persamaan diatas dapat diperoleh satu persamaan:

$$
\mathrm{d} \geqq \sqrt{\frac{4 W}{\pi \tau_{a \times 0,64}}} \text { atau } \mathrm{d} \geqq \sqrt{\frac{2 W}{\tau_{a}}}
$$

Besarnya tekanan kontak pada permukaan ulir:

$$
\mathrm{q}=\frac{W}{\pi d_{2} h z} \leqq \mathrm{qa}
$$

Dimana :

$\mathrm{q}=$ besar tekanan kontak pada permukaan ulir $(\mathrm{kg} / \mathrm{mm} 2)$

$\mathrm{W}=$ Gaya tarik pada baut $(\mathrm{kg})$

$\mathrm{d} 2=$ diameter efektif ulir luar (mm)

$\mathrm{z}=$ jumlah lilitan ulir luar. 
$\mathrm{h}=$ tinggi profil yang bekerja menahan gaya $(\mathrm{mm})$.

$\mathrm{qa}=$ tekanan kontak yang diizinkan $(\mathrm{kg} / \mathrm{mm} 2)$

Jumlah ulir dan tinggi mur $\mathrm{h}$ dapat dihitung dari persamaan:

$$
\mathrm{z}=\frac{W}{\pi d_{2} h q}
$$

$\mathrm{H}=\mathrm{zp} \cdot \mathrm{p}=$ jarak bagi

Menurut Stndar ; $\mathrm{H}=(0,08-1,0) \mathrm{d}$

Untuk mencari besar tegangan geser, digunakan persamaan:

$$
\tau_{\mathrm{b}}=\frac{W}{\pi d_{1} k p z}
$$

Dimana :

k.p = tebal akar ulir luar.

sementara jika tebal akar ulir pada mur dinyatakan dengan j.p maka tegangan gesernya adalah :

$$
\tau_{\mathrm{n}}=\frac{W}{\pi D \cdot j p z} .
$$

Untuk ulir matris dapat diambil $\mathrm{k} \approx 0,84$ dan $\mathrm{j} \approx 0,75$. Untuk pembebanan pada seluruh ulir yang dianggap merata, $\tau$ b dan $\tau$ n harus lebih kecil dari harga yag diizinkan $\tau$ a

\section{Perancangan Mesin Cutting Cheese Blok}

Dari perhitungan yang menggunakan persamaan sesuai yang tertulis pada laman diatas, maka hasil dari perhitungan tersebut ditulis dalam bentuk tabel

\begin{tabular}{|c|c|c|c|c|}
\hline \multicolumn{5}{|c|}{ Perhitungan Pneumatik } \\
\hline No & $\begin{array}{c}\text { Jenis } \\
\text { Perhitungan }\end{array}$ & $\begin{array}{c}\text { Simbo } \\
1\end{array}$ & Hasil & Satuan \\
\hline 1 & Gaya Dorong & $\mathrm{F}$ & 210 & $\begin{array}{l}\text { Newton } \\
(\mathrm{N})\end{array}$ \\
\hline 2 & $\begin{array}{l}\text { Menentukan } \\
\text { Diameter } \\
\text { Batang } \\
\text { Silinder }\end{array}$ & d & 27 & $\begin{array}{l}\text { Mili meter } \\
(\mathrm{mm})\end{array}$ \\
\hline 3 & $\begin{array}{l}\text { Debit } \\
\text { Kompresor }\end{array}$ & Q & 52,78 & $\begin{array}{l}\text { Liter/meni } \\
\mathrm{t}(1 / \mathrm{min})\end{array}$ \\
\hline 4 & $\begin{array}{l}\text { Daya } \\
\text { Kompresor }\end{array}$ & $P_{a d}$ & 2,2 & $\begin{array}{l}\text { KiloWatt } \\
(\mathrm{kW})\end{array}$ \\
\hline 5 & $\begin{array}{l}\text { Daya Poros } \\
\text { kompresorr }\end{array}$ & $\mathrm{P}_{\mathrm{s}}$ & 3,14 & $\begin{array}{l}\text { Kilowatt } \\
(\mathrm{kW})\end{array}$ \\
\hline 6 & $\begin{array}{l}\text { Daya Motor } \\
\text { kompresor }\end{array}$ & $\mathrm{P}_{\mathrm{m}}$ & 3,454 & $\begin{array}{l}\text { Kilowatt } \\
(\mathrm{kW})\end{array}$ \\
\hline 7 & $\begin{array}{l}\text { Waktu } \\
\text { pemotongan } \\
\text { langkah maju }\end{array}$ & $\mathrm{t}_{\text {maju }}$ & 3,1 & Detik (S) \\
\hline 8 & $\begin{array}{l}\text { Waktu } \\
\text { pemotongan } \\
\text { langkah } \\
\text { mundur }\end{array}$ & $\mathrm{t}_{\text {mundur }}$ & 2,9 & Detik (S) \\
\hline 9 & $\begin{array}{l}\text { Watu Satu } \\
\text { kali } \\
\text { pemotongan }\end{array}$ & $\mathrm{t}_{\text {tot }}$ & 6 & Detik (S) \\
\hline 10 & $\begin{array}{l}\text { Gaya efektif } \\
\text { piston saat } \\
\text { maju }\end{array}$ & $\mathrm{F}_{\mathrm{a}}$ & 4417,2 & $\begin{array}{l}\text { Newton } \\
\text { (N) }\end{array}$ \\
\hline
\end{tabular}
seperti berikut :

\begin{tabular}{|c|c|c|c|c|}
\hline 11 & $\begin{array}{l}\text { Gaya efektif } \\
\text { piston saat } \\
\text { mundur }\end{array}$ & $\mathrm{F}_{\mathrm{b}}$ & 4095 & $\begin{array}{l}\text { Newton } \\
(\mathrm{N})\end{array}$ \\
\hline 12 & $\begin{array}{l}\text { Konsumsi } \\
\text { udara saat } \\
\text { piston maju }\end{array}$ & $\mathrm{V}_{1}$ & 11 & Liter \\
\hline 13 & $\begin{array}{l}\text { Konsumsi } \\
\text { udara saat } \\
\text { piston } \\
\text { mundur }\end{array}$ & $\mathrm{V}_{2}$ & 10,8 & Liter \\
\hline 14 & $\begin{array}{l}\text { Konsumsi } \\
\text { udara total }\end{array}$ & $\mathrm{V}_{\text {tot }}$ & 21,8 & Liter \\
\hline 15 & $\begin{array}{l}\text { Konsumsi } \\
\text { udara tiap } \\
\text { menit langkah } \\
\text { maju }\end{array}$ & $\mathrm{Q}_{1}$ & 135 & $\begin{array}{l}\text { Liter/meni } \\
\text { t }(\mathrm{L} / \mathrm{min})\end{array}$ \\
\hline 16 & $\begin{array}{l}\text { Konsumsi } \\
\text { udara tiap } \\
\text { menit langkah } \\
\text { mundur }\end{array}$ & $\mathrm{Q}_{2}$ & 124 & $\begin{array}{l}\text { Liter/meni } \\
\mathrm{t}(\mathrm{L} / \mathrm{min})\end{array}$ \\
\hline \multicolumn{5}{|c|}{ Perhitungan Gaya Gesek } \\
\hline 1 & $\begin{array}{l}\text { Gaya Vertikal } \\
\text { Benda }\end{array}$ & $F_{x}$ & 210 & $\begin{array}{l}\text { Newton } \\
(\mathrm{N})\end{array}$ \\
\hline 2 & $\begin{array}{l}\text { Gaya } \\
\text { Horizantal } \\
\text { Benda }\end{array}$ & $\mathrm{F}_{\mathrm{y}}$ & 0 & $\begin{array}{l}\text { Newton } \\
(\mathrm{N})\end{array}$ \\
\hline 3 & Gaya Normal & $\mathrm{F}_{\mathrm{N}}$ & 147 & $\begin{array}{l}\text { Newton } \\
\text { (N) }\end{array}$ \\
\hline 4 & $\begin{array}{l}\text { Gaya gesek } \\
\text { statis }\end{array}$ & $f_{\mathrm{s}}$ & 5,88 & $\begin{array}{l}\text { Newton } \\
(\mathrm{N})\end{array}$ \\
\hline 5 & $\begin{array}{l}\text { Gaya gesek } \\
\text { kinetik }\end{array}$ & $f_{\mathrm{k}}$ & 5,88 & $\begin{array}{l}\text { Newton } \\
(\mathrm{N})\end{array}$ \\
\hline 6 & Percepatan & $\mathrm{a}$ & 13,6 & $\mathrm{~m} / \mathrm{s}^{2}$ \\
\hline 7 & Perlambatan & $\mathrm{a}^{\prime}$ & 0,68 & $\mathrm{~m} / \mathrm{s}^{2}$ \\
\hline \multicolumn{5}{|c|}{ Perhitungan Dan perencanaan Rangka } \\
\hline 1 & $\begin{array}{l}\text { Reaksi Pada } \\
\text { titik A }\end{array}$ & RA & 30,065 & $\begin{array}{l}\text { Kilogram } \\
(\mathrm{Kg})\end{array}$ \\
\hline 2 & $\begin{array}{l}\text { Reaksi Pada } \\
\text { titik E }\end{array}$ & $\mathrm{RE}$ & 24,935 & $\begin{array}{l}\text { Kilogram } \\
(\mathrm{Kg})\end{array}$ \\
\hline 3 & $\begin{array}{l}\text { Momen di } \\
\text { titk A }\end{array}$ & $\mathrm{M}_{\mathrm{A}}$ & 0 & $\mathrm{Kgcm}$ \\
\hline 4 & $\begin{array}{l}\text { Momen di } \\
\text { titk B }\end{array}$ & $\mathrm{M}_{\mathrm{B}}$ & 841,42 & $\mathrm{Kgcm}$ \\
\hline 5 & $\begin{array}{l}\text { Momen di } \\
\text { titk C }\end{array}$ & $\mathrm{M}_{\mathrm{C}}$ & $\begin{array}{l}1724,6 \\
8\end{array}$ & $\mathrm{Kgcm}$ \\
\hline 6 & $\begin{array}{l}\text { Momen di } \\
\text { titk D }\end{array}$ & $\mathrm{M}_{\mathrm{D}}$ & $\begin{array}{l}1246,7 \\
6 \\
\end{array}$ & $\mathrm{Kgcm}$ \\
\hline 7 & $\begin{array}{l}\text { Momen di } \\
\text { titik E }\end{array}$ & $\mathrm{ME}_{\mathrm{E}}$ & 0 & $\mathrm{Kgcm}$ \\
\hline 8 & $\begin{array}{l}\text { Daya lintang } \\
\text { A-B }\end{array}$ & $\mathrm{D}_{\mathrm{A}-\mathrm{B}}$ & 30,065 & $\begin{array}{l}\text { Kilogram } \\
(\mathrm{Kg})\end{array}$ \\
\hline 9 & $\begin{array}{l}\text { Daya lintang } \\
\text { B-C }\end{array}$ & Dв-с & 20,065 & $\begin{array}{l}\text { Kilogram } \\
(\mathrm{Kg})\end{array}$ \\
\hline 10 & $\begin{array}{l}\text { Daya lintang } \\
\text { C-D }\end{array}$ & $\mathrm{D}_{\mathrm{C}-\mathrm{D}}$ & $-14,935$ & $\begin{array}{l}\text { Kilogram } \\
(\mathrm{Kg})\end{array}$ \\
\hline 11 & $\begin{array}{l}\text { Daya lintang } \\
\text { D-E }\end{array}$ & D $_{\text {D-E }}$ & $-24,935$ & $\begin{array}{l}\text { Kilogram } \\
(\mathrm{Kg})\end{array}$ \\
\hline 12 & Safety factor & - & 6,62 & $\mathrm{Kg} / \mathrm{mm}^{2}$ \\
\hline 13 & $\begin{array}{l}\text { Tegangan } \\
\text { tarik izin }\end{array}$ & $\tau_{\mathrm{izin}}$ & 5,302 & $\mathrm{Kg} / \mathrm{mm}^{2}$ \\
\hline \multicolumn{5}{|c|}{ Perhitungan baut dan mur komponen cutter } \\
\hline 1 & Diameter inti & $\mathrm{d}$ & 4,51 & $\mathrm{Mm}$ \\
\hline 2 & $\begin{array}{l}\text { Beban tiap } \\
\text { bagian } \\
\text { sambungan }\end{array}$ & W & 98 & $\begin{array}{l}\text { Newton } \\
(\mathrm{N})\end{array}$ \\
\hline
\end{tabular}

Tabel 1. Hasil perhitungan rangcangan. 


\begin{tabular}{|l|l|l|l|l|}
\hline 3 & $\begin{array}{l}\text { Gaya akibat } \\
\text { pengencanga } \\
\text { n }\end{array}$ & $f$ & 107,8 & $\begin{array}{l}\text { Newton } \\
(\mathrm{N})\end{array}$ \\
\hline 4 & $\begin{array}{l}\text { Gaya yang } \\
\text { diterima tiap } \\
\text { baut }\end{array}$ & $\mathrm{FS}$ & 26,95 & $\begin{array}{l}\text { Newton } \\
(\mathrm{N})\end{array}$ \\
\hline 5 & Jumlah ulir & $\mathrm{Z}$ & 2,5 & $\mathrm{Mm}$ \\
\hline 6 & Tinggi mur & $\mathrm{H}$ & 4,8 & $\mathrm{Mm}$ \\
\hline 7 & $\begin{array}{l}\text { Tegangan } \\
\text { geser yang } \\
\text { terjadi }\end{array}$ & $\tau_{\mathrm{b}}$ & 1,47 & $\mathrm{Kg} / \mathrm{mm}^{2}$ \\
\hline \multicolumn{5}{|c|}{ Menghitung kekerasan keju dan cutter } \\
\hline 1 & $\begin{array}{l}\text { Nilai } \\
\text { kekerasan } \\
\text { Keju }\end{array}$ & $\begin{array}{l}\text { BHN- } \\
\text { Keju }\end{array}$ & 0,22 & - \\
\hline 2 & $\begin{array}{l}\text { Nilai } \\
\text { kekerasan } \\
\text { Cutter }\end{array}$ & $\begin{array}{l}\text { BHN- } \\
\text { Cutter }\end{array}$ & 147 & - \\
\hline
\end{tabular}

Dari hasil perhitungan dan perancangan yang dilakukan didapat spesifikasi, yaitu :

Spesifikasi silinder Pneumatik

Tipe Silinder pneumatik : silinder kerja ganda Tipe DSBC

Diameter Silinder $\quad: 125 \mathrm{~mm}=0,125 \mathrm{~m}$

Diameter Batang $\quad: 32 \mathrm{~mm}=0,032 \mathrm{~m}$

Panjang langkah $\quad: 225 \mathrm{~mm}=0,225 \mathrm{~m}$

Spesifikasi Motor Kompresor

Dimeter silinder $\quad: 80 \mathrm{~mm}$

Dimeter batang $\quad: 25 \mathrm{~mm}$

Panjang langkah $\quad: 60 \mathrm{~mm}$

Kecepatan $\quad: 175 \mathrm{~mm} /$ detik

Rpm : $: 550$

Jumlah silinder $\quad: 2$

Daya kompresor $\quad: 2,2 \mathrm{~kW}$

Spesifikasi baut dan mur cutting tool

Jumlah baut $=4$ buah

Jumlah mur $=4$ buah

Bahan baut dan mur = baja liat dengan 0,22\% C

Ukuran baut dan mur = M6

Tinggi mur $=4,8 \mathrm{~mm}$

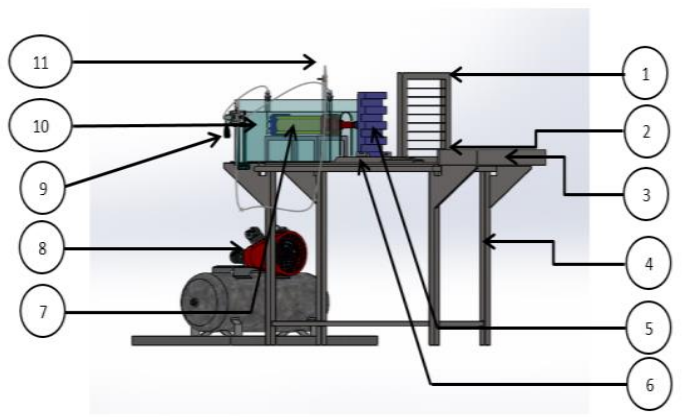

1. Pisau Pemotong

7. Silinder Pnuematic

2. Rel

3. Meja Mesin

8. Tabung Udara

4. Rangka

5. Pendorong Keju

6. Teflon

4. Hasil dan Pembahasan

Pemotongan Manual
Dalam proses pemotongan keju secara manual diketahui bahwa jenis keju merupakan keju blok dengan berat sebesar $20 \mathrm{~kg}$ dan mempunyai panjang $50 \mathrm{~cm}$, lebar $25 \mathrm{~cm}$ dan tebal $20 \mathrm{~cm}$. Waktu yang diperlukan untuk satu kali pemotongan adalah 75 menit, itu berarti dalam satu hari kerja keju yang dapat dipotong adalah sebagai berikut : $\frac{8 \times 60}{75}=6,4$ blok keju

Pemotongan Menggunakan Mesin Pemotong Keju

Dari perhitungan secara teoritis didapat waktu satu kali pemotongan adalah 9, 264 detik, ditambah waktu loading material 15 menit atau 900 detik, sehingga waktu yang diperlukan untuk satu kali peroses pemotongan adalah 909,264 detik, maka dalam satu hari kerja mesin dan operator dapat memotong keju sebanyak : $\frac{8 \times 3600}{909,265}=31,65$ blok keju. Itu artinya efisiensi operator dalam bekerja bisa meningkat hingga 4,9 x lipat dari senelumnya.

\section{Kesimpulan}

Perancangan mesin pemotong keju dengan kapasitas $20 \mathrm{~kg}$ sangat membantu dunia industri pangan khususnya yang bergerak di bidang penguat rasa dan industri keju yang mengedepankan kualitas dan kuantitas hasil kerja. Berdasarkan perhitungan secara teoritis mesin pemotong keju mampu meningkatkan kuantitas dan kualitas dari hasil pemotongan. Dengan desain mesin yang sederhana diharapkan mudah dalam pengoprasian dan perawatannya. Pemotongan Keju secara manual menghasilkan ukuran yang tidak seragam dan jumlahnya 6,4 Blok sedangkan menggunakan mesin hasil ukuran dapat seragam dan dari jumlah dapat mencapai 31,65 Blok.

\section{Daftar Pustaka}

Buckle, K.A., R.A. Edward, G.H. Fleet dan Wootton. 2007. Ilmu Pangan. Edisi ke-4. Terjemahan: Hari Purnomo dan Adiono. UI-Press. Jakarta

Murti, T. W. dan Hidayat, T. 2009. Pengaruh Pemakaian Kultur Tiga Macam Bakteri Asam Laktat dan Pemeraman Terhadap Komposisi Kimia dan Flavour Keju. Journal of The Indonesian Tropical Animal Agriculture. 34 (1) : 10-15.

Sari, N. A., A. Sustiyah dan A.M. Legowo. 2014. Total bahan padat, kadar protein, dan nilai kesukaan keju mozarella dari kombinasi susu kerbau dan susu sapi. Jurnal Aplikasi Teknologi Pangan. 3(4): 152-156.

Winarno, F. G dan I. E. Fernandez. 2007. Susu dan Produk Fermentasinya. Bogor: M-Brio Press

Nurhidayati, T., 2003. Pengaruh Konsentrasi Enzim Papain dan Suhu Fermentasi Terhadap Kualitas Keju Cottage, FMIPA-ITS Surabaya. 
Balia, R. L. 2006. Perlunya Perhatian terhadap Keberadaan Yeast dalam Produk Makanan Kaitannya dengan Kesehatan Masyarakat. Laboratorium Pengolahan Hasil Peternakan Fakultas Peternakan Universitas Padjajaran. Hal : 5 .

Murti, T. W. 2002. Pasca Produksi Susu dan Tata Lingkungan Usaha Persususan. Yogyakarta: Fakultas Peternakan UGM

Sutomo, Budi. 2006. Mengenal Keju dan Manfaat Bagi Kesehatan. [terhubung berkala].http://budiboga.blogspot.com/2006/0 5/pernah-gagal-membuat-kue-kering baca.html [10/03/2012]

Amima Siti. 2015. Pengembangan Alat Pemotong Tipe Manual Menjadi Stick Kentang (Solanum Tuberosum). Padang: Fakultas Teknologi Pertanian Universitas Andalas.

Syawaldi. 2016. Perencanaan Dan Perancangan Mekanisme Mesin Sebagai Alat Pemotong Umbin - Umbian (Ubi Kayu/Singkong) Untuk Meningkatkan Usaha Industri Kecil Menengah (Ikm). Riau: fakultas Teknik Universitas Islam.

Saputra Twintha Omega dan Paulus Wisnu Anggoro. 2016. Inovasi Desain Perontok Padi Untuk Meningkatkan Efektifitas Hasil Panen. Yogyakarta: Fakultas Teknik Universitas Atma Jaya.

Supriadi, 2001. Perancangan Alat Pengiris Sukun. Politeknik Negeri Medan, Medan.

Budiyanto. 2012. Perancangan Mesin Perajang Singkong. Yogyakarta: Fakultas Teknik Universitas Yogyakarta.

Giesecke et al. 2001. Gambar Teknik, Jilid 1. Edisi ke-11. Jakarta: Erlangga

Hurst, K. S. (2006) Prinsip-prinsip Perancangan Teknik. Alih Bahas. Edited by L. Simarmata and S. Mariani. Jakarta: Penerbit Erlangga.

Krist Thomas. 1993. Dasar Dasar Pneumatik. Alih Bahasa Dines Ginting. Jakarta: Erlangga.

Sumbodo Wirawan; DKK. 2008. Teknik Produksi Mesin Industri-Jilid 3. Jakarta: Direktorat Pembinaan Sekolah Menengah Kejuruan.

Andrew Parr. 2003. Hidrolika Dan Pneumatika. Alih Bahasa Gunawan Prasetyo. Jakarta: Erlangga

Popov, E.P. 1989. Mekanika Teknik. Alih bahasa Zainul Astmar Fanisan. Jakarta: Erlangga

Sularso, Haruo Tahara. 2000. Pompa Dan Kompresor. Jakarta: Pradnya Paramita.

Kamarawan Sidharta S. 1984. Statika : Bagian Dari Mekanika Teknik. Jakarta : Universitas Indonesia ( UI Press ).

Peter Croser, Frank Ebel. 2002. Pneumatics - Basic Leve Festo Didactic TP 101. Denkendorf : Festo Didactic Gmbh \& Co

Drs. Sugihartono. 1996. Dasar - Dasar Kontrol Pneumatik. Bandung : Tarsito.
Irawan Agustinus Purna. 2017. Diklat Kuliah Mekanika Teknik (Statika Struktur). Jakarta : Universitas Tarumanegara.

Sularso, Kiyokatsu Suga. 1997. Dasar Perencanaan Dan pemilihan Elemen Mesin. Jakarta: Pradnya Paramita.

Irawan Agustinus Purna. 2009. Diklat Kuliah Elmen Mesin. Jakarta : Universitas Tarumanegara.

Yuniarto Arif. 2017. Modul Limit Swict Dan Sensor Pada Pneumatik Dan Electo Pneumatik. Jakarta : Direktorat Pendidikan Sekolah Menengah Kejuruan.

Widoro Ego. 2015. Perhitungan Kapasitas Dan Tekanan Kerja Kompresor Udara Pada Sheet Metal Shop. Tanggerang: Aviansi Langit Biru.

Sugiyono, 2007. Metode Penelitian Kuantitatif Kualitatif Dan R\&D. Bandung : Alfabeta

\section{Lampiran}

Lampiran Gambar Mesin 

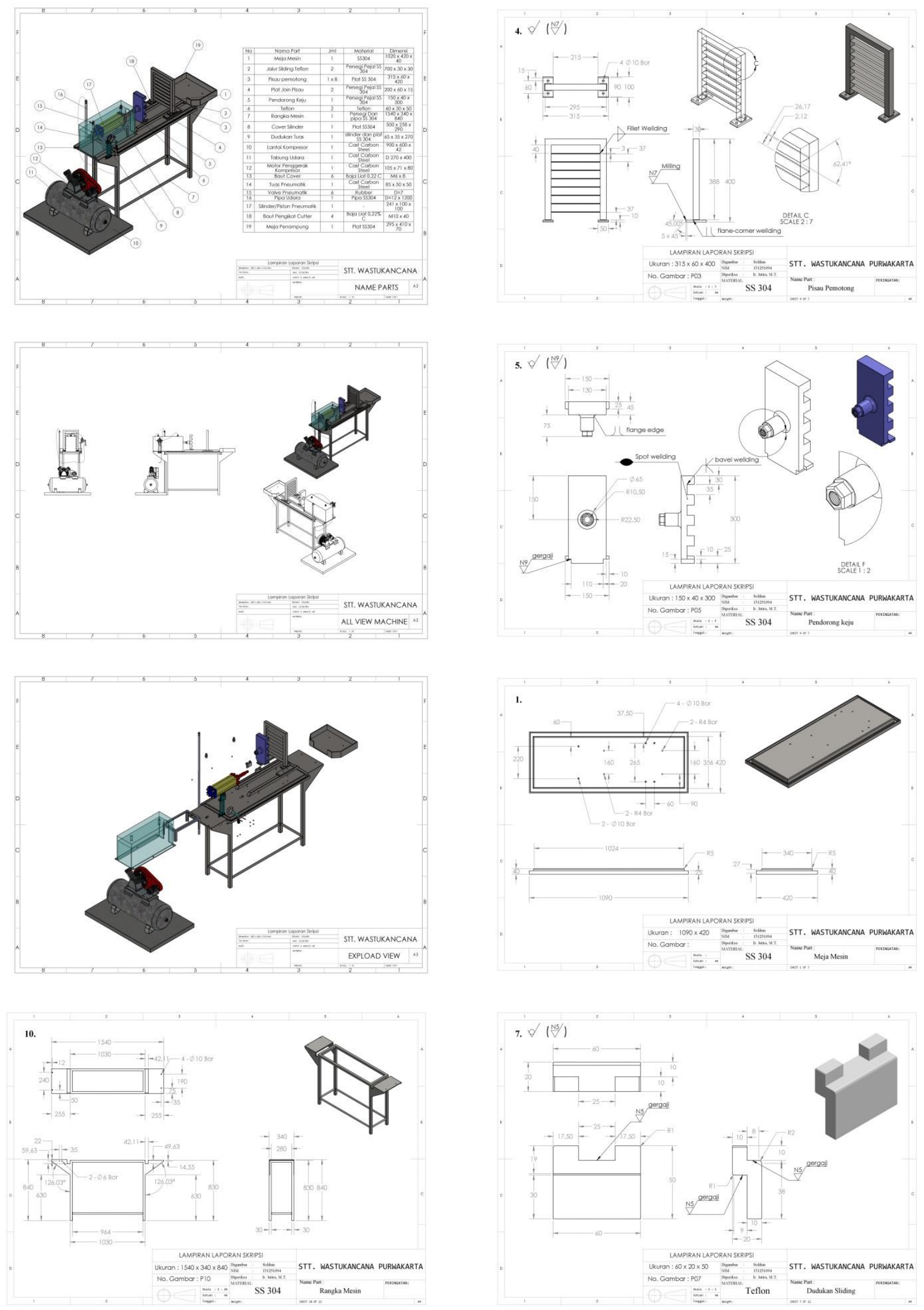